\title{
Nitrogen Time of Application Impact on Productivity, Water Use Efficiency and Agronomic Efficiency of Maize in a Semi-arid Environment
}

\author{
S. Lamptey ${ }^{1,2,3}$, Lingling $\mathrm{Li}^{1,2} \&$ Junhong Xie ${ }^{1,2}$ \\ ${ }^{1}$ Gansu Provincial Key Lab of Arid Land Crop Science, Lanzhou, China \\ ${ }^{2}$ College of Agronomy, Gansu Agricultural University, Lanzhou, China \\ ${ }^{3}$ University for Development Studies, Tamale, Ghana \\ Correspondence: Lingling Li, College of Agronomy, Gansu Agricultural University, No.1 Yingmencun, Anning \\ District, Lanzhou 730070, China. Tel: 86-931-760-3751.E-mail: lill@gsau.edu.cn
}

Received: April 23, $2018 \quad$ Accepted: May 27, $2018 \quad$ Online Published: July 15, 2018

doi:10.5539/jas.v10n8p72 URL: https://doi.org/10.5539/jas.v10n8p72

This research is financed by the National Natural Science Foundation of China (31460337, 31660373 and 31761143004), and Education Department of Gansu Province (2017C-12).

\begin{abstract}
Water is one of the most important limiting factor of rainfed continuous maize (Zea mays L.) cropping systems in northwest of China. A three continuous year field experiments were conducted to study the influence of different nitrogen time of application on grain yield and water use efficiency of maize (Zea mays L.) in the Western Loess plateau. The experiment was laid in a randomized complete block design with two treatments and three replicates. Treatments were; (one-third application of $\mathrm{N}$ at sowing + two-third application at pre-flowering) and (one-third application of $\mathrm{N}$ at sowing + one-third pre-flowering + one-third at milking) as $\mathrm{T}_{1}$ and $\mathrm{T}_{2}$ respectively. The results showed that, $T_{1}$ significantly increased grain yield by $9 \%$ in 2014 and 2016; and WUE by $11 \%$ in 2016 compared to $T_{2} . T_{1}$ increased $\mathrm{AE}$ by $43 \%$ compared to $T_{2}$. Our results indicate that $1 / 3$ application of Nitrogen at sowing and $2 / 3$ application of Nitrogen at pre-flowering $\left(\mathrm{T}_{1}\right)$ for maize is more appropriate for sustainable maize production in terms of satisfactory grain- $\mathrm{N}$ recoveries and low environmental losses of $\mathrm{N}$ fertilizer.
\end{abstract}

Keywords: maize, nitrogen nutrition, time of application, plant pigments

\section{Introduction}

In dryland cropping systems, soil water availability and Nitrogen content are among the major factors limiting crop production (Sainju et al., 2009). The continuous depletion of soil organic matter and the extensive soil erosion in the Loess plateau has caused rapid decline in soil fertility (Wang et al., 2013). The depleted nature of the Loess soils coupled with limited precipitation and high evaporation of the area often results in low crop yield (Liu et al., 2009). Nitrogen fertilization plays a significant role in improving soil fertility and increasing crop productivity (Malhi \& Lemke, 2007). However, under the best management practices, $30-50 \%$ of applied $\mathrm{N}$ is lost through different agencies. Several studies (e.g., Tilman et al., 2002; Canfield et al., 2010) have also shown that nitrogen $(\mathrm{N})$ use efficiency (NUE) in Loess plateau is relatively low $(\approx 20 \%)$ compared with values of NUE reported for maize elsewhere (e.g., $\geq 30 \%$, Herrera et al., 2016). The low NUE has negative implication on the environmental as well as agronomic and economic implications for growers. In an attempt to resolve this, strategies such as using the optimum $\mathrm{N}$ rate and time of application have been developed to mitigate nutrient leaching and improve the nutrient use efficiency (NUE). Optimum rate and time of $\mathrm{N}$ application can enhance yield productivity and nutrient use efficiencies while reducing the environmental pollution (Nielsen, 2013). Nitrogen timing of application is one of the methods to improve nitrogen use by the crop while reducing the nutrient loss through leaching and volatilization (Muthukumar et al., 2007) and increase the economic benefit (Sitthaphanit et al., 2010). Time of $\mathrm{N}$ application can increase the recovery of applied $\mathrm{N}$ up to $58-70 \%$ and hence increase yield and grain quality of the crop (Haile et al., 2012). 
Soil moisture shortages commonly occur as a result of limited rainfall and strong evaporation in the semiarid. However, low water use efficiency aggravates water stress (Fang et al., 2012). According to (Puppala et al., 2005) water use efficiency (WUE) is one of the ways to analyze the response of crops to different conditions of water availability as it relates to the production of dry biomass or commercial production with the amount of water applied. It is therefore important to increase food production with lower water use (Perry et al., 2009). Improving nitrogen use efficiency, grain yield and WUE is important for sustainable crop production in dryland farming systems. Many studies have reported on nitrogen rate, however, reports on $\mathrm{N}$ time of application are scanty. We hypothesized that maize grain yield; water use efficiency and agronomic efficiency are enhanced by timing of nitrogen application. To achieve this, the study investigated the influence of nitrogen timing of application on grain yield of maize, water use efficiency and agronomic efficiency in the Western Loess Plateau of China.

\section{Materials and Methods}

\subsection{Site Description}

The field experiments were conducted in 2014, 2015 and 2016 cropping season at the Dingxi Experimental Station $\left(35^{\circ} 28^{\prime} \mathrm{N}, 104^{\circ} 44^{\prime} \mathrm{E}\right.$ and elevation $\left.1971 \mathrm{~m}\right)$, Gansu Province, northwest China. The site had sandy loamy soil with $\mathrm{pH}$ of 8.3 , soil organic carbon below $7.63 \mathrm{~g} / \mathrm{kg}$ and Olsen P below $13.3 \mathrm{mg} / \mathrm{kg}$. The Long-term annual rainfall at the experimental site averages $391 \mathrm{~mm}$ ranging from $246 \mathrm{~mm}$ in 1986 to $564 \mathrm{~mm}$ in 2003 with about $54 \%$ received between July and September. Annual accumulated temperature $>10{ }^{\circ} \mathrm{C}$ is $2239{ }^{\circ} \mathrm{C}$. The experiment was set up in 2012. In-crop season rainfall recorded at the site during the course of the experiment was $280 \mathrm{~mm}$ in 2014, $274 \mathrm{~mm}$ in 2015, and $227 \mathrm{~mm}$ in 2016.

\subsection{Experimental Design}

The experiment used a randomized complete block design with two treatments and three replicates. Treatments were: (one-third $\mathrm{N}$ application at sowing + two-third $\mathrm{N}$ at pre-flowering) and (one-third $\mathrm{N}$ at sowing + one-third pre- flowering + one-third at milking) as $\mathrm{T}_{1}$ and $\mathrm{T}_{2}$, respectively. Nitrogen application at $300 \mathrm{~kg} \mathrm{ha}^{-1}$ before sowing is the commonest farmer practice in the area. All treatments received phosphorus $\left(\mathrm{P}_{2} \mathrm{O}_{5}\right)$ application at $150 \mathrm{~kg} \mathrm{ha}^{-1}$. Pre-plant $\mathrm{N}$ and $\mathrm{P}_{2} \mathrm{O}_{5}$ fertilizers were incorporated during ploughing, whereas in-crop season $\mathrm{N}$ was applied using a hand-held drill device. Plots were mulched using plastic films at sowing to improve soil temperature for germination, and also to reduce evaporative losses. The use of plastic film mulching is an innovative technology used in maize to facilitate crop establishment and increase productivity in arid environments (Gan et al., 2013). The maize (Zea mays L., cv. Funong 821) was sown using a row spacing of $0.55 \mathrm{~m}$ to achieve a density of 52,000 plants ha ${ }^{-1}$.

\subsection{Measurement and Methods for Calculating Indices}

\subsubsection{Leaf Area Index}

Five (5) plants were sampled using the "S" type method from each plot at seedling stage, flowering stage and milking stage. The leaf length (ai) and the greatest leaf width (bi) were measured using ruler. Leaf area of crop was determined by leaf length $\times$ the greatest leaf width $\times 0.75$ (i.e., the compensation coefficient of maize is 0.75). Leaf area index (LAI) was calculated using the equation described by Lamptey et al. (2017):

$$
L A I=0.75 \cdot P \cdot \sum_{i=1}^{n} a i \times b i
$$

Where, $P$ is maize planting density.

\subsubsection{Chlorophyll Content}

Chlorophyll content per unit leaf area was estimated from chlorophyll content measured at VN, R1 and R3 stages using portable chlorophyll meter (SPAD Model 502, Minolta Camera Co. Osaka, Japan) from 09:00 to 12:00 on ten randomly fully expanded leaves per plot.

\subsubsection{Photosynthetic Activities}

Diurnal variations of gs, $\mathrm{P}_{\mathrm{N}}, \mathrm{E}$ and $\mathrm{Ci}$, were measured on a cloudless day at 2-hour intervals (i.e., 0800 to 1800 ) using a portable gas exchange fluorescent system (GFS-3000, Heinz Walz GmbH). Stomata limitation $\left(\mathrm{L}_{\mathrm{S}}\right)$ was calculated using Equation described by Lamptey et al. (2017):

$$
L_{S}=1-\mathrm{Ci} / \mathrm{Ca}
$$

The gas exchange device was used under the following conditions: flow rate of air through the chamber was 750 mmol s${ }^{-1}$, the concentration of $\mathrm{CO}_{2}$ was $393.3 \mathrm{mg} \mathrm{kg}^{-1}, \mathrm{H}_{2} \mathrm{O}$ concentration was $14,598 \mathrm{mg} \mathrm{kg}^{-1}$, area was $8 \mathrm{~cm}^{2}$, and temperature was $24.7^{\circ} \mathrm{C}$. Measurements were done at flowering and milking stage on three randomly 
selected maize plants from the inner rows of the plots by selecting one leaf per plant. Measurements were often conducted near the center of the youngest and uppermost fully expanded leaf exposed to full sunlight.

\subsubsection{Grain Yield}

At physiological maturity, maize was harvested manually from an area of $13.2 \mathrm{~m}^{2}(4 \mathrm{~m} \times 3.3 \mathrm{~m})$ per plot. Grains were separated from the cob, weighed and converted into $\mathrm{kg}$ per hectare. The aboveground biomass and grain yield were determined on dry weight basis by oven-drying at $105{ }^{\circ} \mathrm{C}$ for $45 \mathrm{~min}$ and subsequently dried to constant weight at $85^{\circ} \mathrm{C}$ (Lamptey et al., 2017).

\subsubsection{Water Consumption and Water Use Efficiency}

Volumetric soil water content (\%) was measured at sowing and maturity stages using Trime-Pico IPH (Precise Soil Moisture Measurement, IMKO Micromodul technik GmbH, Ettlingen, Germany). Subsequently, soil water storage was extrapolated from the volumetric soil water content by multiplying it with the layer depth.Water consumption (ET) was estimated using Equation (3) described in Lamptey et al. (2017):

$$
E T=P-\Delta W
$$

Where, $P$ is total precipitation for the growing season, and $\Delta W$ is the difference between soil water storage at sowing and water storage at harvest, respectively. All parameters were expressed in millimeters $(\mathrm{mm})$. Drainage was not considered because previous studies conducted at the experimental site reported no significant drainage during the growing season (Huang et al., 2008).

Grain water-use efficiency $\left(\mathrm{WUE}_{\mathrm{g}}\right.$ ) was determined based on soil water content measured at $0-110 \mathrm{~cm}$ depth interval using Equation 4 described in Lamptey et al. (2017):

$$
W U E_{g}=\frac{Y}{E T}
$$

Where, $W U E_{g}$ is grain water use efficiency, $Y$ is grain yield $\left(\mathrm{kg} \mathrm{ha}^{-1}\right)$, and $E T$ is total water consumption over the entire growing season $(\mathrm{mm})$.

\subsubsection{Agronomic Efficiency (AE)}

Agronomic efficiency was determined using the difference method as described in Lamptey et al. (2017):

$$
A E=\frac{\left(Y_{F}-Y_{F=0}\right)}{F_{\text {Rate }}}
$$

Where, $Y_{F}$ and $Y_{F=0}$ are the yield of the fertilized and non-fertilized crops, respectively, and $F_{\text {Rate }}$ is the amount of nutrient applied.

\subsection{Statistical Analyses}

Statistical analyses were undertaken with the Statistical Package for the Social Sciences 22.0 (IBM Corporation, 2013). In the present studies, treatments were used as a fixed effect whereas year was used as a random effect. Differences between the means were determined using the least significance difference test at $5 \%$ probability level $(p<0.05)$.

\section{Results}

\subsection{Leaf Area Index}

Data for leaf area index (LAI) for all years is shown in Figure 1. Leaf area index increased with maturity and then start to decrease after 120 days after sowing (DAS). Leaf area index were greatest in 2014, followed by 2015 and 2016. Fertilizer time of application had appreciable effect on LAI with $\mathrm{T}_{1}$ having the highest LAI and $\mathrm{T}_{2}$ having the least values at almost every stage measured. Treatment $\mathrm{T}_{1}$ averagely increased LAI by $10 \%$ compared with $\mathrm{T}_{2}$. 


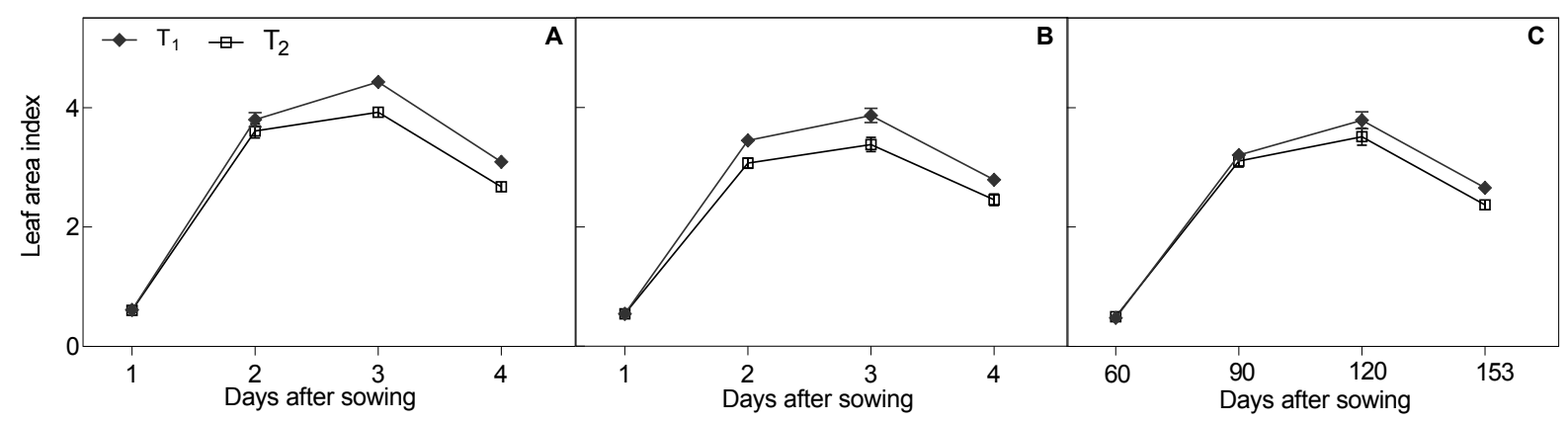

Figure 1. Leaf area index (LAI) of maize measured in 2014 (A), 2015 (B) and 2016 (C) under different time of N application. Error bars denote the standard error of means

\subsection{Chlorophyll Content}

Fertilizer timing of application had appreciable effect on chlorophyll content (Figure 2). Values reported under chlorophyll content correspond to the mean of three growth stages for each year. The highest chlorophyll content was observed for nitrogen applied $1 / 3$ at planting and $2 / 3$ at pre-flowering which resulted to $T_{1}$ averagely increasing chlorophyll content by $7 \%$ compared with $\mathrm{T}_{2}$.

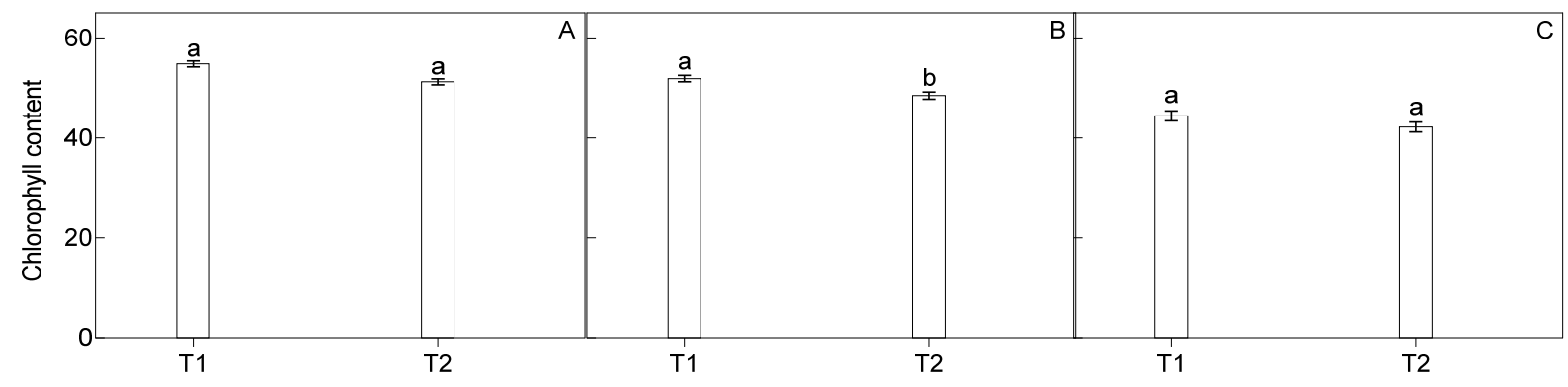

Figure 2. Chlorophyll content (SPAD) of maize measured in 2014 (A), 2015 (B) and 2016 (C) under different nitrogen time of application. Error bars denote the standard error of means. Bars with different letters in the same year are significantly different

\subsection{Photosynthetic Activities}

Photosynthesis showed similar peak times and daily patterns at flowering and milking (critical stages). Therefore, the values reported in this experiment represent the mean of both growth stages for each year. The average results of Stomatal conductance (gs), net photosynthetic rate $\left(\mathrm{P}_{\mathrm{N}}\right)$, transpiration rate $(\mathrm{E})$, intercellular $\mathrm{CO}_{2}$ concentration $(\mathrm{Ci})$ and stomatal limitation $\left(\mathrm{L}_{\mathrm{S}}\right)$ is presented in Table 1 and 2 . Time of application and year significantly influenced all photosynthetic activities with the exception of transpiration rate, however, their interaction showed no significance (Table 1). The gs, $\mathrm{P}_{\mathrm{N}}$, and $\mathrm{E}$ values presented in Table 2 are means averaged across all diurnal sample times and growth stages for a given year. Average values for gs, $\mathrm{P}_{\mathrm{N}}, \mathrm{E}, \mathrm{Ci}$ and $\mathrm{L}_{\mathrm{s}}$ differed significantly between treatments within and between years. On average, $1 / 3 \mathrm{~N}$ at sowing $+2 / 3 \mathrm{~N}$ pre-flowering $\left(\mathrm{T}_{1}\right)$ increased gs $(15 \%), \mathrm{P}_{\mathrm{N}}(12 \%), \mathrm{E}(13 \%)$ compared to $\mathrm{T}_{2}$ (Table 2). The Ci and $\mathrm{L}_{\mathrm{S}}$ values were significantly higher in $\mathrm{T}_{2}$ compared with $\mathrm{T}_{1}$. Generally, treatments with high gs, $\mathrm{P}_{\mathrm{N}}$, and $\mathrm{E}$ had lower $\mathrm{Ci}$ and $\mathrm{L}_{\mathrm{S}}$, and vice versa.

Table 1. Analysis of variance for nitrogen time of application, year and their interaction on photosynthetic activities

\begin{tabular}{llllll}
\hline Source & $\mathrm{gs}$ & $\mathrm{P}_{\mathrm{N}}$ & $\mathrm{E}$ & $\mathrm{Ci}$ & $\mathrm{Ls}$ \\
\hline Time $(\mathrm{T})$ & $* *$ & $*$ & $* *$ & $*$ & $*$ \\
Year $(\mathrm{Y})$ & $*$ & $*$ & $\mathrm{~ns}$ & $* *$ & $*$ \\
$\mathrm{~T} * \mathrm{Y}$ & $\mathrm{ns}$ & $\mathrm{ns}$ & $\mathrm{ns}$ & $* *$ & $\mathrm{~ns}$ \\
\hline
\end{tabular}


Table 2. Stomatal conductance $\left(\mathrm{gs}, \mathrm{mol}\left(\mathrm{H}_{2} \mathrm{O}\right) \mathrm{m}^{-2} \mathrm{~s}^{-1}\right)$, net assimilation rate $\left(\mathrm{P}_{\mathrm{N}}, \mu \mathrm{mol} \mathrm{m} \mathrm{m}^{-2} \mathrm{~s}^{-1}\right)$, transpiration rate $\left(\mathrm{E}, \mathrm{mmol}\left(\mathrm{H}_{2} \mathrm{O}\right) \mathrm{m}^{-2} \mathrm{~s}^{-1}\right)$, intercellular $\mathrm{CO}_{2}$ concentration $\left(\mathrm{Ci}, \mu \mathrm{mol}\left(\mathrm{CO}_{2}\right) \mathrm{mol}^{-1}\right)$ and stomatal limitation $\left(\mathrm{L}_{\mathrm{S}}\right)$ in maize under different time of application. The data represent an average across all diurnal sample times and growth stages of each replicate prior to statistical analysis

\begin{tabular}{lllllll}
\hline Year & Treatment & gs & $\mathrm{P}_{\mathrm{N}}$ & $\mathrm{E}$ & $\mathrm{Ci}$ & $\mathrm{Ls}$ \\
\hline 2014 & $\mathrm{~T}_{1}$ & 149.85 & 9.50 & 3.59 & 293.71 & 0.17 \\
& $\mathrm{~T}_{2}$ & 131.74 & 8.50 & 3.18 & 305.16 & 0.17 \\
\hdashline 015 & LSD & $\mathbf{1 1 . 1 9}$ & $\mathbf{0 . 3 7}$ & $\mathbf{0 . 1 8}$ & $\mathbf{1 2 . 3 8}$ & $\mathbf{0 . 0 4}$ \\
& $\mathrm{T}_{1}$ & 134.73 & 7.76 & 3.28 & 301.55 & 0.19 \\
& $\mathrm{~T}_{2}$ & 117.92 & 6.92 & 2.88 & 307.02 & 0.19 \\
2016 & LSD & $\mathbf{6 . 2 6}$ & $\mathbf{0 . 3 4}$ & $\mathbf{0 . 3 1}$ & $\mathbf{5 . 1 2}$ & $\mathbf{0 . 0 2}$ \\
& $\mathrm{T}_{1}$ & 114.44 & 4.25 & 3.26 & 316.74 & 0.17 \\
& $\mathrm{~T}_{2}$ & 98.76 & 3.75 & 2.89 & 320.98 & 0.18 \\
\hline
\end{tabular}

\subsection{Biomass and Grain Yield}

Time of $\mathrm{N}$ application, year, and their interactions had significant effects on biomass and grain yield (Table 3). Biomass and grain yield in 2016 were significantly lower than that in 2014 and 2015 (Table 4). One-third N at sowing and two-third at pre-flowering $\left(\mathrm{T}_{1}\right)$ significantly increased biomass and grain yield by 18 and $9 \%$ in 2014 , 9 and $6 \%$ in 2015 and 5 and $6 \%$ in 2016, respectively compared with $\mathrm{T}_{2}$. In terms of biomass and grain yield, it was found better to apply $1 / 3 \mathrm{~N}$ at planting and the remaining $2 / 3$ at pre-flowering $\left(\mathrm{T}_{1}\right)$.

Table 3. Analysis of variance for nitrogen time of application, year and their interaction on biomass and grain yield

\begin{tabular}{lll}
\hline Source of variation & Biomass Yield & Grain Yield \\
\hline Time $(\mathrm{T})$ & $* * *$ & $*$ \\
Year $(\mathrm{Y})$ & $* * *$ & $* *$ \\
$\mathrm{~T} * \mathrm{Y}$ & $* * *$ & $*$ \\
\hline
\end{tabular}

Table 4. Biomass and grain yield $\left(\mathrm{kg} \mathrm{ha}^{-1}\right)$ of maize as affected by nitrogen time of application

\begin{tabular}{llllllll}
\hline \multirow{2}{*}{ Treatment } & \multicolumn{3}{c}{ Biomass yield } & & \multicolumn{3}{c}{ Grain yield } \\
\cline { 2 - 4 } & 2014 & 2015 & 2016 & & 2014 & 2015 & 2016 \\
\hline $\mathrm{T}_{1}$ & 20519 & 18789 & 8466 & & 7654 & 7143 & 4151 \\
$\mathrm{~T}_{2}$ & 17337 & 17296 & 8103 & & 6995 & 6713 & 3826 \\
LSD (0.05) & $\mathbf{2 0 9 8}$ & $\mathbf{1 7 6 1}$ & $\mathbf{2 2 0 2}$ & & $\mathbf{5 8 0}$ & $\mathbf{4 8 4}$ & $\mathbf{3 1 4}$ \\
\hline
\end{tabular}

\subsection{Agronomic Efficiency}

Result on agronomic efficiency is presented in Figure 3; $\mathrm{T}_{1}$ significantly increased AE in 2014 by $53 \%$, in 2015 by $41 \%$ and in 2016 by 29 compared to $\mathrm{T}_{2}$. This indicates that much productivity improvement was gained by applying nitrogen at $T_{1}$ in the study area. The highest AE was observed when $\mathrm{N}$ was applied in two splits $\left(\mathrm{T}_{1}\right)$ compared to three splits $\left(\mathrm{T}_{2}\right)$. 


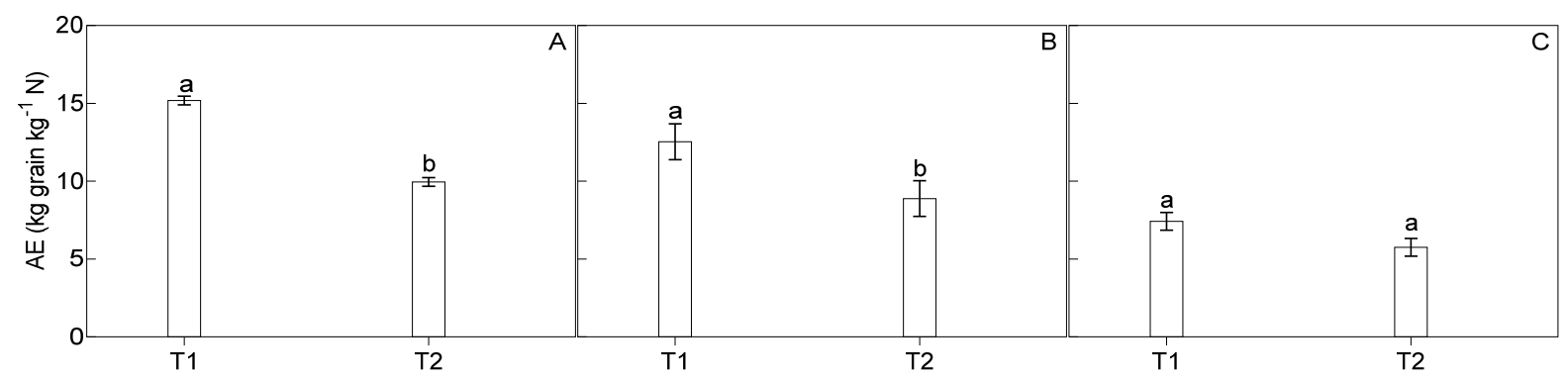

Figure 3. Agronomic efficiencies recorded in 2014(A), 2015 (B) and 2016 (C). Bars with different letters in the same year are significantly different at $(P<0.05)$ by the least significance difference test

\subsection{Water Consumption and Water Use Efficiency}

Water consumption (ET) and water use efficiency $\left(\mathrm{WUE}_{\mathrm{g}}\right)$ is presented in Table 5 and 6 . Overall, nitrogen time of application, year and its interaction showed significant differences $(\mathrm{P}<0.05)$ in ET and $\mathrm{WUE}_{\mathrm{g}}($ Table 5). Water consumption in $T_{1}$ was higher in 2015 and 2016 compared with $T_{2}$. Application of $T_{1}$ significantly increased $\mathrm{WUE}_{\mathrm{g}}$ in 2014 compared to $\mathrm{T}_{2}$, however, 2015 and 2016 showed no significant difference (Table 6).

Table 5. Analysis of variance for nitrogen time of application, year and their interaction on water consumption (ET) and grain water use efficiency $\left(\mathrm{WUE}_{\mathrm{g}}\right)$

\begin{tabular}{lll}
\hline Source of variation & ET & WUE $_{\mathrm{g}}$ \\
\hline Time $(\mathrm{T})$ & $*$ & $*$ \\
Year $(\mathrm{Y})$ & $* * *$ & $* *$ \\
$\mathrm{~T} * \mathrm{Y}$ & $*$ & $*$ \\
\hline
\end{tabular}

Note. *, ${ }^{* *}, * * *$ indicate significant difference at $P<0.05, P<0.01, P<0.001$ respectively. n.s. indicate no significance.

Table 6. Water consumption (ET, mm) and grain water use efficiency (WUE $\mathrm{kg} \mathrm{ha}^{-1} \mathrm{~mm}^{-1}$ ) in maize under different time

\begin{tabular}{llllllll}
\hline \multirow{2}{*}{ Source } & \multicolumn{3}{c}{ ET } & & \multicolumn{3}{c}{ WUE $_{\mathrm{g}}$} \\
\cline { 2 - 3 } \cline { 7 - 9 } & 2014 & 2015 & 2016 & & 2014 & 2015 & 2016 \\
\hline $\mathrm{T}_{1}$ & 264.14 & 288.59 & 263.84 & & 28.89 & 24.52 & 15.67 \\
$\mathrm{~T}_{2}$ & 268.10 & 280.98 & 251.03 & & 26.11 & 23.7 & 15.20 \\
LSD (0.05) & $\mathbf{9 . 8 1}$ & $\mathbf{6 . 5 4}$ & $\mathbf{5 . 7 4}$ & & $\mathbf{1 . 5 2}$ & $\mathbf{2 . 0 0}$ & $\mathbf{2 . 8 2}$ \\
\hline
\end{tabular}

\section{Discussion}

Differences in leaf area can affect plant spatial distribution and the microenvironment within population (Fageria et al., 2006), which plays a significant role in the photosynthetic efficiency of crops. In the current study, leaf area index and chlorophyll content were major indicators of the trends in the photosynthetic traits as they explained more than $95 \%$ of the photosynthetic variability. The improved crop physiological parameters under $\mathrm{T}_{1}$ indicate the potential of nitrogen application time which may result in marked increase in grain yield. Studies have indicated that synchronizing the $\mathrm{N}$ supply with crop $\mathrm{N}$ demand is crucial for improving crop yields (Chen et al., 2011). Timing of nitrogen application based on crop $\mathrm{N}$ requirement is important to increase the $\mathrm{N}$ use efficiency and to improve the effective partitioning and translocation of assimilates from source to sink in field crops (Solaimalai et al., 2001). Time of application significantly enhances $\mathrm{N}$ absorption, particularly at the time of critical $\mathrm{N}$ requirement for the crop (Haile et al., 2012). The highest agronomic efficiency under $\mathrm{T}_{1}$ suggested improved $\mathrm{N}$ uptake by the crop and reduced environmental losses of N. Ahrens et al. (2010) reported that improvement in nitrogen use efficiency is a key issue for sustainable and profitable nitrogen use in high-input agriculture. Other reports also confirmed that split application of $\mathrm{N}$ after the good establishment of the crop markedly reduces $\mathrm{N}$ losses (Sawyer, 2008). Increased water consumption in $T_{1}$ fertilization compared to $T_{2}$ is a result of increased aboveground biomass and increase water loss from the crop canopy due to higher 
evapotranspiration (ET) rates, as shown in earlier studies (e.g., Lamptey et al., 2017; Nielsen \& Halvorson, 1991). It also denotes more efficient conversion of water into biomass and improved partitioning (Calviño et al., 2003). This, resulting to higher $\mathrm{WUE}_{\mathrm{g}}$ in $\mathrm{T}_{1}$ suggesting beneficial yield response through optimized water balance in co-growth period allowing more water used for transpiration to supporting maize growth.

\section{Conclusion}

Findings suggest that $\mathrm{T}_{1}$ (one-third $\mathrm{N}$ application at sowing + two-third $\mathrm{N}$ pre-flowering) increased WUEg through improved response of maize to leaf area index, chlorophyll content and photosynthetic activity compared with $\mathrm{T}_{2}$. One-third $\mathrm{N}$ at sowing and two-third at pre-flowering $\left(\mathrm{T}_{1}\right)$ also enhanced agronomic efficiency. Therefore, $\mathrm{N}$ time of application to crop need to be adjusted and determined to sustain biomass and grain yield in these semiarid regions.

\section{Acknowledgements}

This research is financed by the National Natural Science Foundation of China (31460337, 31660373 and 31761143004), and Education Department of Gansu Province (2017C-12). We are also grateful to students of the Dingxi Experimental Station, Gansu Agricultural University for their assistance.

\section{References}

Ahrens, T. D., Lobell, B., Ortiz-Monasterio, J. I., Li, Y., \& Matson, P. A. (2010). Narrowing the agronomic yield gap with improved nitrogen use efficiency: A modeling approach. Ecological Applications, 20(1), 91-100. https://doi.org/10.1890/08-0611.1

Calviño, P. A., Andrade, F. H., \& Sadras, V. O. (2003). Maize yield as affected by water availability, soil depth, and crop management. Agronomy Journal, 95, 275-281. https://doi.org/10.2134/agronj2003.2750

Canfield, D. E., Glazer, A. N., \& Falkowski, P. G. (2010). The evolution and future of earth's nitrogen cycle. Science, 330, 192-196. https://doi.org/10.1126/science.1186120

Chen, X. P., Cui, X. L., Vitousek, P. M., Cassman, K. G., Matson, P. A., Bai, J. S., ... Zhang, F. S. (2011). Integrated soil-crop system management for food security. Proceedings of the National Academy of Science, USA, 108(16), 6399-6404. https://doi.org/10.1073/pnas.1101419108

Fageria, N. K., \& Baligar, V. C. (2005). Enhancing nitrogen use efficiency in crop plants. Advances in Agronomy, 88, 97-185. https://doi.org/10.1016/S0065-2113(05)88004-6

Fang, Q., Ma, L., Yu, Q., Ahuja, L. R., Malone, R. W., \& Hoogenboom, G. (2010). Irrigation strategies to improve the water use efficiency of wheat-maize double cropping systems in North China Plain. Agricultural Water Management, 97, 1165-1174. https://doi.org/10.1016/j.agwat.2009.02.012

Gan, Y. T., Siddique, K. H. M., Turner, N. C., Li, X. G., Niu, J. Y., \& Yang, C. (2013). Chapter seven: Ridge-furrow mulching systems-An innovative technique for boosting crop productivity in semiarid rain-fed environments. In L. S. Donald (Ed.), Advanced Agronomy Journal (pp. 429-476). Academic Press, Cambridge, MA. https://doi.org/10.1016/B978-0-12-405942-9.00007-4

Haile, D., Nigussie, D., \& Ayana, A. (2012). Nitrogen use efficiency of bread wheat: Effects of nitrogen rate and time of application. Journal of Soil Science and Plant Nutrition, 12(3), 389-410. https://doi.org/10.4067/ S0718-95162012005000002

Herrera, J. M., Rubio, G., Häner, L. L., Delgado, J. A., Lucho-Constantino, C. A., Islas-Valdez, S., \& Pellet, D. (2016). Emerging and established technologies to increase nitrogen use efficiency of cereals. Agronomy, 6, 25. https://doi.org/10.3390/agronomy6020025

Lamptey, S., Li, L., Xie, J., Zhang, R., Yeboah, S., \& Antille, D. (2017). Photosynthetic response of maize (Zea mays L.) to nitrogen fertilization in the semiarid Western Loess Plateau of China. Crop Science, 57(5), 2739-2752. https://doi.org/10.2135/cropsci2016.12.1021

Liu, C. A., Jin, S. L., Zhou, L. M., Jia, Y., Li, F. M., Xiong, Y. C., \& Li, X. G. (2009). Effects of plastic film mulch and tillage on maize productivity and soil parameters. European Journal of Agronomy, 31, 241-249. https://doi.org/10.1016/j.eja.2009.08.004

Malhi, S. S., \& Lemke, R. (2007). Tillage, crop residue and N fertilizer effects on crop yield, nutrient uptake, soil quality and nitrous oxide gas emissions in a second 4-yr rotation cycle. Soil and Tillage Research, 96, 269-283. https://doi.org/10.1016/j.still.2007.06.011 
Muthukumar, V. B., Velayudham, K., \& Thavaprakaash, N. (2007). Plant Growth Regulators and Split Application of Nitrogen Improves the Quality Parameters and Green Cob Yield of Baby Corn (Zea mays L.). Journal of Agronomy, 6(1), 2008-211. https://doi.org/10.3923/ja.2007.208.211

Nielsen, D. C., \& Halvorson, A. D. (1991). Nitrogen fertility influence on water stress and yield of winter wheat. Agronomy Journal, 83, 1065-1070. https://doi.org/10.2134/agronj1991.00021962008300060025x

Nielsen, R. B. (2013). Root Development in Young Corn. Department of Agronomy, Purdue University, USA.

Puppala, N., Fowler, J. L., Jones, T. L., Gutschick, V., \& Murray, L. (2005): Evapotranspiration, Yield, and Water-Use Efficiency Responses of Lesquerella Fendleri at Different Growth Stages. Industrial Crops and Products, 21, 33-47. https://doi.org/10.1016/j.indcrop.2003.12.005

Sainju, U. M., Lenssen, A. W., Caesar-TonThat, T., \& Evans, R. G. (2009). Dryland crop yields and soil organic matter as influenced by long-term tillage and cropping sequence. Agronomy Journal, 101, $243-251$. https://doi.org/10.2134/agronj2008.0080x

Sawyer, J. E. (2008). Nitrogen application timing, forms, and additives. American Society of Agricultural and Biological Engineers.

Sitthaphanit, S., Limpinuntana, V., Toomsan, B., Panchaban, S. W., \& Bell, R. (2010). Growth and Yield Responses in Maize to Split and Delayed Fertilizer Applications on Sandy Soils under High Rainfall Regimes. Kasetsart Journal (Natural Science), 44, 991-1003.

Solaimalai, A., Sivakumar, C., Anbumani, S., Suresh, T., \& Arumugam, K. (2001). Role of plant growth regulators in rice production-a review. Agricultural Review, 22, 33-40.

Tilman, D., Cassman, K. G., Matson, P. A., Naylor, R., \& Polasky, S. (2002). Agricultural sustainability and intensive production practices. Nature, 418, 671-677. https://doi.org/10.1038/nature01014

Wang, D., Yu, Z. W., \& White, P. J. (2013). The effect of supplemental irrigation after jointing on leaf senescence and grain-filling in wheat. Field Crops Research, 151, 35-44. https://doi.org/10.1016/j.fcr.2013.07.009

\section{Copyrights}

Copyright for this article is retained by the author (s), with first publication rights granted to the journal.

This is an open-access article distributed under the terms and conditions of the Creative Commons Attribution license (http://creativecommons.org/licenses/by/4.0/). 